\title{
Quality of Life and Philosophy of Life Determines Physical and Mental Health: Status Over Research Findings From The Quality of Life Research Center, Copenhagen, 1991-2007
}

\author{
Søren Ventegodt ${ }^{1,2,3,4,5}$, Isack Kandel ${ }^{6,}$ and Joav Merrick ${ }^{7,8,9}$ \\ ${ }^{1}$ Quality of Life Research Center, Teglgårdstræde 4-8, DK-1452 Copenhagen K, Denmark; \\ ${ }^{2}$ Research Clinic for Holistic Medicine and ${ }^{3}$ Nordic School of Holistic Medicine, Copenhagen, \\ Denmark; ${ }^{4}$ Scandinavian Foundation for Holistic Medicine, Sandvika, Norway; 5 Interuniversity \\ College, Graz, Austria; ${ }^{6}$ Faculty of Social Sciences, Department of Behavioral Sciences, Ariel \\ University Center, Samaria, Ariel, Israel; ${ }^{7}$ National Institute of Child Health and Human \\ Development, ${ }^{8}$ Office of the Medical Director, Division for Mental Retardation, Ministry of Social \\ Affairs, Jerusalem, Israel and ${ }^{9}$ Kentucky Children's Hospital, University of Kentucky, Lexington, \\ United States \\ E-mail: ventegodt@livskvalitet.org
}

Received July 19, 2007; Revised September 2, 2007; Accepted September 6, 2007; Published October 22, 2007

Quality of life (QOL) has over the past decade become an important part of health science and also increased public awareness. It has become increasingly apparent that illness is closely related to the individual perception of a good life, and therefore the exploration of indicators related to quality of life appears to be of broad importance for the prevention and treatment of diseases. Identifying, which factors constitute a good life may reveal an understanding about what areas in life should be encouraged, in order to enhance the global quality of life, health, and ability. In this paper we present results from studies initiated in $\mathbf{1 9 8 9}$ to examine quality of life in relation to disease. The purpose of this presentation was to assemble the results from the study carried out in the years between 1993 and 1997, examining a total of 11.500 Danes, to show the association between quality of life and a wide series of social indicators.

KEY WORDS: Quality of life, research, holistic health and medicine

\section{INTRODUCTION}

The concept of quality of life (QOL) has become an important topic both in the health field, social welfare and the political debate, especially in the Nordic countries. Enhancing the quality of life is more and more considered to be an objective in treatment and prevention of illness together with the provision of psychosocial support. For the last three decades QOL has been a major issue of debate in Denmark, and in recent years the concept of quality of life or living "a good life" has been the subject of a number of philosophical and psychological studies in Denmark made by other researchers before us (Aggernæs, 1989[1]; Henriksen, 1992[2]; Holm et al, 1994[3]; Kemp, 1991[4]; Sandøe, 1992[5]). It is becoming 
increasingly apparent that illness is closely related to the individual perception of a good life, and therefore the exploration of indicators related to quality of life appears to be of broad importance for the prevention and treatment of diseases.

\section{SEARCH FOR QUALITY OF LIFE}

Our search for describing quality of life was built on the foundation that our quality of life must be composed of items that are known to us. Therefore a comparative valuation of these items must be our chief instrument for deciding the degree of quality of life of the person studied. The best quality of life will be the state that contains the greatest number of items having a positive value according to our own estimate. In order to arrive at correct decisions as to which items should be included in the questionnaire, it was necessary to consider what we would judge to be good and consider what comparative values to attach each item. From this approach we created first the SEQOL (self evaluation of quality of life) questionnaire, and later the much shorter and easier-used QOL1 and QOL5 questionnaires.

Identifying, which factors constitute a good life may reveal an understanding about what areas in life should be encouraged, in order to enhance the global quality of life, health, and ability. In this paper we present results from studies initiated in 1989 to examine quality of life in relation to disease. The purpose of this presentation is to assemble the results from the study carried out in the years between 1993 and 1997, examining a total of 11.500 Danes, to show the association between quality of life and a wide series of social indicators, in the ambition to make an almost complete map of QOL and the factors determining QOL, physical and mental health, and sexual, social and working ability (see the published series of papers below). We include three major lines of indicators: indicators of the present life, indicators of the personal history (life events), and indicators from the beginning of life, including a series of social and biological factors. Our belief was that a part of the variation of QOL in the adult population could be explained by biological and social heritage, another part could be explained by life event - happy and unhappy - and a third part could be explained by the conscious choices in life, recently, here and now.

Much to our surprise, data came out back in 1993-5 that convincingly showed us that our human consciousness seems to be the all-dominating factor that determines our quality of life, health, and ability. This discovery lead us to explore the possibilities for interviewing directly on the issue of human consciousness, and we found three major sources of knowledge on the intervention on the human consciousness for medical reasons: the classical holistic Hippocratic character medicine, which includes conversational therapy, bodywork, and spiritual exercises; the integrative and transcultural medicine that integrates all the medical systems of the pre-mordern cultures which most often also used conversational therapy, bodywork, and spiritual exercises with a major focus on bodywork and spiritual exercises, and the tradition of psychoanalysis and psychodynamic therapy, primarily conversational therapy but in some modern traditions also including bodywork.

In 1997 the Quality of Life Research Center took the initiative to establish an international research team on clinical holistic medicine (CHM) to meet the huge challenge of developing such a contemporary, medical synthesis aiming at integrating all existent consciousness-oriented (holistic) medical knowledge. Around the year 2000 the team had 20 members from three continents working together to create what today is called scientific or clinical, holistic medicine. Substantial funding from the IMK Almene Foundation though all the years - including the four-floor building called "The House of Health" that was created in central Copenhagen with funding of about 4 mill. EUROs, made this research possible. In the research centers at the House of Health we created one on theoretical psychosocial medicine and quality of life (The Quality of Life Research Center) and one on practical psychosocial, complementary and integrative medicine (The Researcxh Clinic for Holistic Medicine) and with this combination the new medical synthesis CHM was developed and tested on 500 volunteers most of them with severe, subjective, chronic health problems (physical, mental, existential and/or sexual issues), which could not be sufficiently helped by biomedicine (drugs or surgery). 


\section{QUALITY OF LIFE RESEARCH CENTER}

The Quality of Life Research Center, housing the Research Clinic for Holistic Medicine, is today a small, private research center, a NGO. It started at the University Hospital of Copenhagen (Rigshospitalet) and became busy in the early 1990s due to substantial funding from among other funds the The Pharmacist Foundation of 1991 and resources from the University hospital. In 1994 it became independent dedicated to understanding the connection between quality of life and health. Its mission is still research and development in quality of life, health and ability, and in the development of these crucial factors in life. To succeed with this hardly manageable mission, the center has from its beginning chosen to work with international networks, and in assuming an abstract and holistic approach to health sciences. The research up to 2004 is reviewed in an earlier paper [6].

\section{RESEARCH FROM THIS CENTER}

The peer-reviewed papers and the scientific books from the QOLRCs research has been published in the following series:

1. QOL methodology (editorial, I-VII)[7-14] describing how global QOL can be measured.

2. QOL philosophy (editorial, I-VI)[15-21] suggesting a holistic way to re-think medical science.

3. QOL theory (I-III)[22-24] describing different ways to understand QOL scientifically.

4. QOL questionnaires (SEQOL, QOL5, QOL1)[25,26] is three validated tools to measure global QOL and subjective physical and mental health.

5. QOL results[27-37] is our statistical findings.

6. Theories of Existence (editorial, I-V)[38-46] is our speculations on the true nature of the human existence (or wholeness, or "soul", or conscious roots of being)

7. Holistic medicine(I-IIII) [47-50]describes our research programs and methods for documenting effects of holistic healing, and the theory for holistic healing in individual therapy and a group setting.

8. QOL as medicine(I-III)[51-53] describes three pilot studies.

9. Clinical holistic medicine(I-VIXXX)[54-90] describes our new synthesis of Hippocratic, transcultural and psychodynamic approaches to consciousness-based medicine.

10. CHM: clinical results[91-96] is the first promising results from the clinical testing of scientific holistic medicine

11. Antonovsky and the sense of coherence[97-102] are 6 important papers testing the connection between sense of coherence and health.

12. Human Development(I-X)[103-112] is a new series of papers going into a deeper exploration of the nature of reality, trying to understand biological information and the connection between matter, life and consciousness.

13. Debate in the BMJ and Danish Medical Journal [113-127] discussed some of the clinical implications of our work. Only recent papers are listed.

14. Other papers $[6,128,129]$ were papers on philosophy of science etc.

15. Scientific books on CHM[130-132] are from a new book series called "Principles of Holistic Medicine (Vol. I-III). Seven more volumes are planned.

In addition the Quality of Life Research Center has published about 10 popular books from the research, and in hundreds of long articles and thousands of small articles in the media/press it has been communicating its research to the public.

More than 100 peer reviewed scientific papers have now been published on quality of life and holistic medicine, making the Quality of Life Research Center one of the worlds most productive centres of new medical knowledge in the field of CAM and clinical holistic medicine - "quality of life as medicine". 
Since 2004 an international community has formed around the research and development of holistic medicine, the International Society for Holistic Health (ISHH) in 2004, and the Quality of Life Research Center has been the host of several international conferences. Through more than 1,000 presentations and lectures at most of the universities and large companies in Denmark the Quality of Life Research Center has made the public understand the fundamental importance of quality of life for health and prevention of illnesses.

After more than 1,000 presentations in the national medias, from the nine a clock news to national TV- and radio programs and the front pages of the leading news papers during the past 14 years, the Danish society at large now seems to have assimilated the key message: that you can improve your QOL and thus prevent disease and even improve your health and ability if you are sick, unhappy or poorly functioning.

\section{THOUGHTS FOR FUTURE PROJECTS}

The most interesting future research project is the the Health Hospital, which is now open for funding; it will take the scientific holistic medicine to the next level, which is the phase 3 clinical studies, documenting the effect of the new drug-free clinical holistic medicine on a large number of patients with many different diseases from cancer, autoimmune diseases, HIV, and chronic pains to schizophrenia and existential, developmental and psycho-sexual problems. $40 \%$ of the Danish population - and the number is pretty much the same in the other European countries and the USA - is suffering from a chronic disease not being cured by biomedicine; we believe as holistic medicine seem to be able to help many of these patients[91-96] that around 2030 most patients will use holistic training programs to prevent and cure diseases instead of just taking bio-medical drugs, which most often is not effective with chronic illness. This is in accordance with the statistics documenting the exponential development in the Danish population's use of CAM and holistic medicine: 400.000 Danes used it in 1990, and 800.000 Danes used it in 2000[133]. If this development continues CAM will be more popular that biomedicine around 2020. It is important to conduct the research now that will make us able to provide efficient and safe holistic medical treatments in the future to the many severely, chronically ill patients that are turning towards scientific holistic medicine and scientific CAM as their last hope.

We therefore sincerely hope that research in holistic medicine and the development of quality of life and health through interventions on the patients' consciousness will be given high priority by governments, private funds and commercial sponsors. We need as the first important step forward with a Holistic Research Hospital, which can be established for around 100 mill. EUROs.

\section{ACKNOWLEDGEMENTS}

The Danish Quality of Life Survey and the Quality of Life Research Center was 1991-2004 supported by grants from the 1991 Pharmacy Foundation, the Goodwill-fonden, the JL-Foundation, E. Danielsen and Wife's Foundation, Emmerick Meyer's Trust, the Frimodt-Heineken Foundation, the Hede Nielsen Family Foundation, Petrus Andersens Fond, Wholesaler C.P. Frederiksens Study Trust, Else \& Mogens WedellWedellsborg's Foundation and IMK Almene Fond. The research was approved by the Copenhagen Scientific Ethical Committee under number (KF)V.100.2123/91 and later correspondance.

\section{REFERENCES}

1. Aggernæs, A, (1989), Quality of life (FADL's Publ, Copenhagen). [Danish]

2. Henriksen, B.L. (1992) Quality of life (Gad, Copenhagen). [Danish] 
3. Holm, P., Holst, J., Olsen, S.B., and B. Perlt (1994) Life and quality in care and pedagogy (Systime, Herning). [Danish]

4. Kemp, P. (1991) The un-replacable (Sprektrum, Copenhagen). [Danish]

5. Sandøe, P. (1992) Quality of life and ethics (Nyt Nordisk Forlag, Arnold Busck, Copenhagen). [Danish]

6. Ventegodt, S., Flensborg-Madsen, T., Andersen, N.J., Nielsen, M., Mohammed, M., and Merrick, J. (2005) Global quality of life (QOL), health and ability are primarily determined by our consciousness. Research findings from Denmark 1991-2004. Social Indicator Research 71, 87-122.

7. Ventegodt, S., Merrick, J., and Andersen, N.J. (2003) Editorial-A new method for generic measuring of the global quality of life. TheScientificWorldJOURNAL 3, 946-949.

8. Ventegodt, S., Hilden, J., and Merrick J. (2003) Measurement of quality of life I: A Methodological Framework. TheScientificWorldJOURNAL 3, 950-961.

9. $\quad$ Ventegodt, S., Merrick, J., and Andersen, N.J. (2003) Measurement of quality of life II. From philosophy of life to science. TheScientificWorldJOURNAL 3, 962-971.

10. Ventegodt, S., Merrick, J., and Andersen, N.J. (2003) Measurement of quality of life III: From the IQOL theory to the global, generic SEQOL questionnaire. TheScientificWorldJOURNAL 3, 972-991.

11. Ventegodt, S., Merrick, J., and Andersen, N.J. (2003) Measurement of quality of life IV: Use of the SEQOL, QOL5, QOL1 and other global and generic questionnaires. TheScientificWorldJOURNAL 3, 992-1001.

12. Ventegodt, S., Merrick, J., and Andersen, N.J. (2003) Measurement of quality of life V: How to use the SEQOL, QOL5, QOL1 and other and generic questionnaires for research. TheScientificWorldJOURNAL 3, 1002-1014.

13. Ventegodt, S., Merrick J., and Andersen N.J. (2003) Measurement of quality of life VI: Quality-adjusted life years (QALY) is an unfortunate use of quality of life concept. TheScientificWorldJOURNAL 3, 1015-1019.

14. Ventegodt, S., Merrick J. (2003) Measurement of quality of life VII: Statistical covariation and global quality of life data. The method of weight-modified linear regression. TheScientificWorldJOURNAL 3, 1020-1029.

15. Ventegodt, S., Andersen N.J., and Merrick, J. (2003) Quality of life philosophy: when life sparkles or can we make wisdom a science? TheScientificWorldJOURNAL 3, 1160-1163.

16. Ventegodt, S., Andersen, N.J., and Merrick, J. (2003) QOL philosophy I: Quality of life, happiness, and meaning of life. TheScientificWorldJOURNAL 3, 1164-1175.

17. Ventegodt, S., Andersen, N.J, Kromann, M., and Merrick, J. (2003) QOL philosophy II: What is a human being? TheScientificWorldJOURNAL 3, 1176-1185.

18. Ventegodt, S., Merrick, J., and Andersen, N.J. (2003) QOL philosophy III: Towards a new biology. TheScientificWorldJOURNAL 3, 1186-1198.

19. Ventegodt, S., Andersen, N.J., and Merrick, J. (2003) QOL philosophy IV: The brain and consciousness. TheScientificWorldJOURNAL 3, 1199-1209.

20. Ventegodt, S., Andersen, N.J., and Merrick, J. (2003) QOL philosophy V: Seizing the meaning of life and getting well again. TheScientificWorldJOURNAL 3, 1210-1229.

21. Ventegodt, S., Andersen, N.J., Merrick, J. (2003) QOL philosophy VI: The concepts. TheScientificWorldJOURNAL 3:1230-40

22. Ventegodt, S., Merrick, J., and Andersen N.J. (2003) Quality of life theory I. The IQOL theory: An integrative theory of the global quality of life concept. TheScientificWorldJOURNAL 3, 1030-1140.

23. Ventegodt, S., Merrick, J., Andersen, N.J. (2003) Quality of life theory II. Quality of life as the realization of life potential: A biological theory of human being. TheScientificWorldJOURNAL 3, 1041-1049.

24. Ventegodt, S., Merrick, J., and Andersen, N.J. (2003) Quality of life theory III. Maslow revisited. TheScientificWorldJOURNAL 3,1050-1057.

25. Ventegodt, S., Henneberg, E.W., Merrick, J., and Lindholt, J.S. (2003) Validation of two global and generic quality of life questionnaires for population screening: SCREENQOL \& SEQOL. TheScientificWorldJOURNAL 3, 412421.

26. Lindholt, J.S., Ventegodt, S., and Henneberg, E.W. (2002) Development and validation of QoL5 for clinical databases. A short, global and generic questionnaire based on an integrated theory of the quality of life. Eur J Surg 168, 103-107.

27. $\quad$ Ventegodt, S. (1998) Sex and the quality of life in Denmark. Arch Sex Behaviour 27(3), 295-307.

28. Ventegodt, S. (1998) A prospective study on quality of life and traumatic events in early life - 30 year follow-up. Child Care Health Dev 25(3), 213-221.

29. Ventegodt, S. and Merrick, J. (2003) Long-term effects of maternal smoking on quality of life. Results from the Copenhagen Perinatal Birth Cohort 1959-61. TheScientificWorldJOURNAL 3, 714-720.

30. Ventegodt, S. and Merrick, J. (2003) Long-term effects of maternal medication on global quality of life measured with SEQOL. Results from the Copenhagen Perinatal Birth Cohort 1959-61. TheScientificWorldJOURNAL 3, 707713.

31. Ventegodt, S. and Merrick, J. (2003) Psychoactive drugs and quality of life. TheScientificWorldJOURNAL 3, 694706.

32. Ventegodt, S. and Merrick, J. (2003) Lifestyle, quality of life and health. TheScientificWorldJOURNAL 3, 811-825.

33. Ventegodt, S., Flensborg-Madsen, T., Andersen, N.J., and Merrick J. (2005). The health and social situation of the mother during pregnancy and global quality of life of the child as an adult. Results from the prospective 
Copenhagen Perinatal Cohort 1959-1961.

34. Ventegodt, S., Flensborg-Madsen, T., Anderson, N.J., and Merrick, J. (2005) Factors during pregnancy, delivery and birth affecting global quality of life of the adult child at long-term follow-up. Results from the prospective Copenhagen Perinatal Birth Cohort 1959-1961.

35. Ventegodt, S., Flensborg-Madsen, T., Andersen, N.J., and Merrick, J. (2005) Events in pregnancy, delivery, and infancy and long-term effects on global quality of life: results from the Copenhagen Perinatal Birth Cohort 1959-61. Med Sci Monit. 11(8), CR357-65. Epub 2005 Jul 25.

36. Ventegodt, S., Flensborg-Madsen, T., Andersen, N.J., Morad, M., and Merrick, J. (2006) Quality of life and events in the first year of life. Results from the prospective Copenhagen Birth Cohort 1959-1961. TheScientificWorldJOURNAL. 6, 106-115.

37. Ventegodt, S., Flensborg-Madsen, T., Andersen, N.J., and Merrick, J. (2006) What influence do major events in life have on our later quality of life? A retrospective study on life events and associated emotions. Med Sci Monit. 12(2), SR9-15. Epub 2006 Jan 26.

38. Ventegodt, S., Andersen, N.J., and Merrick, J. (2003) Editorial: Five theories of human existence. TheScientificWorldJOURNAL 3, 1272-1276

39. Ventegodt, S. (2003) The life mission theory: A theory for a consciousness-based medicine. Int. J. Adolesc. Med. Health 15(1), 89-91.

40. Ventegodt, S., Andersen, N.J., and Merrick, J. (2003) The life mission theory II: The structure of the life purpose and the ego. TheScientificWorldJOURNAL 3, 1277-1285.

41. Ventegodt, S., Andersen, N.J., and Merrick, J. (2003) The life mission theory III: Theory of talent. TheScientificWorldJOURNAL 3, 1286-1293.

42. Ventegodt, S. and Merrick, J. (2003) The life mission theory IV. A theory of child development. TheScientificWorldJOURNAL 3, 1294-1301.

43. Ventegodt, S., Andersen, N.J., and Merrick, J. (2003) The life mission theory V. A theory of the anti-self and explaining the evil side of man. TheScientificWorldJOURNAL 3, 1302-1313.

44. Ventegodt, S., Andersen, N.J., and Merrick, J. (2003) The life mission theory VI: A theory for the human character. TheScientificWorldJOURNAL 4, 859-880.

45. Ventegodt, S., Flensborg-Madsen, T., Andersen, N.J., and Merrick J. (2005) Life Mission Theory VII: Theory of existential (Antonovsky) coherence: a theory of quality of life, health and ability for use in holistic medicine. TheScientificWorldJOURNAL 5, 377-389.

46. Ventegodt, S. Merrick, J: Life mission theory VIII: A theory for pain. J Pain Management. Submitted 2007

47. Ventegodt, S., Andersen, N.J., and Merrick, J. (2003) Holistic medicine: Scientific challenges. TheScientificWorldJOURNAL 3, 1108-1116.

48. Ventegodt, S., Andersen, N.J., and Merrick, J. (2003) Holistic Medicine II: The square-curve paradigm for research in alternative, complementary and holistic medicine: A cost-effective, easy and scientifically valid design for evidence based medicine. TheScientificWorldJOURNAL 3, 1117-1127.

49. Ventegodt, S., Andersen, N.J., and Merrick, J. (2003) Holistic Medicine III: The holistic process theory of healing. TheScientificWorldJOURNAL 3, 1138-1146.

50. Ventegodt, S., Andersen, N.J., and Merrick, J. (2003) Holistic Medicine IV: Principles of the holistic process of healing in a group setting. TheScientificWorldJOURNAL 3, 1294-1301.

51. Ventegodt, S., Andersen, N.J., and Merrick, J. (2003), Quality of life as medicine. A pilot study of patients with chronic illness and pain. TheScientificWorldJOURNAL 3, 520-532.

52. Ventegodt, S., Andersen, N.J., and Merrick, J. (2003), Quality of life as medicine II. A pilot study of a five-day “Quality of Life and Health” cure for patients with alcoholism. TheScientificWorldJOURNAL 3, 842-852.

53. Ventegodt, S., Clausen, B., Langhorn, M., Kroman, M., Andersen, N.J., and Merrick, J. (2004) Quality of Life as Medicine III. A qualitative analysis of the effect of a five days intervention with existential holistic group therapy or a quality of life course as a modern rite of passage. TheScientificWorldJOURNAL 4, 124-133.

54. Ventegodt, S. (in press) Every Contact With the Patient Must Be Therapeutic. Journal of Pediatric and Adolescent Gynecology

55. Ventegodt, S. and Merrick, J. (2005) Psychosomatic reasons for chronic pains. South Med J. 98(11), 1063.

56. Ventegodt, S. and Merrick J. (2004) Clinical holistic medicine: Applied consciousness-based medicine. TheScientificWorldJOURNAL 4, 96-99.

57. Ventegodt, S., Morad, M., and Merrick, J. (2004) Clinical holistic medicine: Classic art of healing or the therapeutic touch. TheScientificWorldJOURNAL 4, 134-147.

58. Ventegodt, S., Morad, M., and Merrick, J. (2004) Clinical holistic medicine: The "new medicine”, the multiparadigmatic physician and the medical record. TheScientificWorldJOURNAL 4, 273-285.

59. Ventegodt, S., Morad, M., and Merrick, J. (2004) Clinical holistic medicine: Holistic pelvic examination and holistic treatment of infertility. TheScientificWorldJOURNAL 4, 148-158.

60. Ventegodt, S., Morad, M., Hyam, E., and Merrick, J. (2004) Clinical holistic medicine: Use and limitations of the biomedical paradigm TheScientificWorldJOURNAL 4, 295-306.

61. Ventegodt, S., Morad, M., Kandel, I., and Merrick, J. (2004) Clinical holistic medicine: Social problems disguised as illness. TheScientificWorldJOURNAL 4, 286-294. 
62. Ventegodt, S., Morad, M., Andersen, N.J., and Merrick, J. (2004) Clinical holistic medicine Tools for a medical science based on consciousness. TheScientificWorldJOURNAL 4, 347-361.

63. Ventegodt S, Morad M, and Merrick J. (2004) Clinical holistic medicine: Prevention through healthy lifestyle and Quality of life. Oral Health Prev Dent. 1, 239-245.

64. Ventegodt, S., Morad, M., Hyam, E., and Merrick, J. (2004) Clinical holistic medicine: When biomedicine is inadequate. TheScientificWorldJOURNAL 4, 333-346.

65. Ventegodt, S., Morad, M., and Merrick, J. (2004) Clinical holistic medicine: Holistic treatment of children. TheScientificWorldJOURNAL 4, 581-588.

66. Ventegodt, S., Morad, M., and Merrick, J. (2004) Clinical holistic medicine: Problems in sex and living together. TheScientificWorldJOURNAL 4, 562-570.

67. Ventegodt, S., Morad, M., Hyam, E., and Merrick, J. (2004) Clinical holistic medicine: Holistic sexology and treatment of vulvodynia through existential therapy and acceptance through touch. TheScientificWorldJOURNAL 4, 571-580.

68. Ventegodt, S., Flensborg-Madsen, T., Andersen, N.J., Morad, M., and Merrick, J. (2004) Clinical holistic medicine: A Pilot on HIV and Quality of Life and a Suggested treatment of HIV and AIDS. TheScientificWorldJOURNAL 4, 264-272.

69. Ventegodt, S., Morad, M., and Merrick, J. (2004) Clinical holistic medicine: Induction of Spontaneous Remission of Cancer by Recovery of the Human Character and the Purpose of Life (the Life Mission). TheScientificWorldJOURNAL 4, 362-377.

70. Ventegodt, S., Morad, M., Kandel, I., and Merrick, J. (2004) Clinical holistic medicine: Treatment of physical health problems without a known cause, exemplified by hypertension and tinnitus. TheScientificWorldJOURNAL 4, 716724.

71. Ventegodt, S., Morad, M., and Merrick, J. (2004) Clinical holistic medicine: Developing from asthma, allergy and eczema. TheScientificWorldJOURNAL 4, 936-942.

72. Ventegodt, S., Morad, M., Press, J., Merrick, J., and Shek, D. (2004) Clinical holistic medicine: Holistic adolescent medicine. TheScientificWorldJOURNAL 4, 551-561.

73. Ventegodt, S., Solheim, E., Saunte, M.E. Morad, M., Kandel, I., and Merrick, J. (2004) Clinical holistic medicine: Metastatic cancer. TheScientificWorldJOURNAL 4, 913-935.

74. Ventegodt, S., Morad, M., Kandel, I., and Merrick, J. (2004) Clinical holistic medicine: a psychological theory of dependency to improve quality of life. TheScientificWorldJOURNAL 4, 638-648.

75. Ventegodt, S. and Merrick, J. (2005) Clinical holistic medicine: Chronic infections and autoimmune diseases. TheScientific WorldJOURNAL 5, 155-164.

76. Ventegodt, S., Kandel, I., Neikrug, S., and Merrick, J. (2005) Clinical holistic medicine: Holistic treatment of rape and incest traumas. TheScientificWorldJOURNAL 5, 288-297.

77. Ventegodt, S., Morad, M., and Merrick, J. (2004) Clinical holistic medicine: Chronic pain in the locomotor system. TheScientificWorldJOURNAL 5,165-172.

78. Ventegodt, S. and Merrick, J (2005) Clinical holistic medicine: Chronic pain in internal organs. TheScientificWorldJOURNAL 5, 205-210.

79. Ventegodt, S. Kandel, I., Neikrug, S. and Merrick, J. (2005) Clinical holistic medicine: The existential crisis - life crisis, stress and burnout. TheScientificWorldJOURNAL 5, 300-312.

80. Ventegodt, S., Gringols, G., and Merrick, J. (2005) Clinical holistic medicine: Holistic rehabilitation. TheScientificWorldJOURNAL 5, 280-287.

81. Ventegodt, S., Andersen, N.J., Neikrug, S., Kandel, I., and Merrick, J (2005) Clinical holistic medicine: Mental disorders in a holistic perspective. TheScientificWorldJOURNAL 5, 313-323.

82. Ventegodt, S., Andersen, N.J., Neikrug, S., Kandel, I. and Merrick, J (2005) Clinical Holistic Medicine: Holistic Treatment of Mental Disorders. TheScientificWorldJOURNAL 5, 427-445.

83. Ventegodt, S. and Merrick, J. (2005) Clinical holistic medicine: The patient with multiple diseases TheScientificWorldJOURNAL 5, 324-339.

84. Ventegodt, S., Clausen, B., Nielsen, M.L., and Merrick, J. (2006) Advanced tools for holistic medicine. TSW Holistic Health \& Medicine 1, 84-101. DOI 10.1100/tswhhm.2006.31.

85. Ventegodt, S., Clausen, B., and Merrick, J. (2006) Clinical holistic medicine: The case story of Anna: I. Long term effect of child sexual abuse and incest with a treatment approach. TSW Holistic Health \& Medicine. 1, 1-12.

86. Ventegodt, S., Morad, M., and Merrick, J. (2006) Clinical holistic medicine: the case story of Anna. II. Patient diary as a tool in treatment. TSW Holistic Health \& Medicine 1, 42-70.

87. Ventegodt, S., Morad, M., and Merrick, J. (2006) Clinical holistic medicine: The case story of Anna. III. Rehabilitation of philosophy of life during holistic existential therapy for childhood sexual abuse. TSW Holistic Health \& Medicine, 1, 102-113.

88. Ventegodt, S. and Merrick, J. (2005) Suicide from a holistic point of view. TheScientificWorldJOURNAL 5,759-766.

89. Ventegodt, S., Clausen, B., and Merrick, J. (2006) Clinical holistic medicine: Holistic sexology and acupressure through the vagina (Hippocratic pelvic massage). TSW Holistic Health \& Medicine 1, 104-127.

90 Ventegodt, S., Clausen, B., and Merrick, J. (2006) Clinical holistic medicine: Pilot study on the effect of vaginal acupressure (Hippocratic pelvic massage). TSW Holistic Health \& Medicine 1, 136-152. 
91. Ventegodt, S., Thegler, S., Andreasen, T., Struve, F., Enevoldsen, L., Bassaine, L., Torp, M., and Merrick, J. (2006) Clinical Holistic Medicine: Psychodynamic Short-Time Therapy Complemented with Bodywork. A Clinical Follow-Up Study of 109 Patients. TSW Holistic Health \& Medicine 1, 256-227.

92. Ventegodt, S., Thegler, S., Andreasen, T., Struve, F., Enevoldsen, L., Bassaine, L., Torp, M., and Merrick J. (2007) Clinical holistic medicine (mindful, short-term psychodynamic psychotherapy complemented with bodywork) in the treatment of experienced impaired sexual functioning. TheScientificWorldJOURNAL 7, 324-329.

93. Ventegodt, S., Thegler, S., Andreasen, T, Struve, F., Enevoldsen, L., Bassaine, L., Torp, M., and Merrick J. (2007). Clinical holistic medicine (mindful, short-term psychodynamic psychotherapy complemented with bodywork) improves quality of life, health, and ability by induction of Antonovsky-salutogenesis. TheScientificWorldJOURNAL.7, 317-323.

94. Ventegodt, S., Thegler, S., Andreasen, T., Struve, F., Enevoldsen, L., Bassaine, L., Torp, M., and Merrick, J. (2007). Clinical holistic medicine (mindful, short-term psychodynamic psychotherapy complemented with bodywork) in the treatment of experienced physical illness and chronic pain. TheScientificWorldJOURNAL. 7, 310316.

95. Ventegodt, S., Thegler, S., Andreasen, T., Struve, F., Enevoldsen, L., Bassaine, L., Torp, M., and Merrick, J. (2007) Clinical holistic medicine (mindful, short-term psychodynamic psychotherapy complemented with bodywork) in the treatment of experienced mental illness. TheScientificWorldJOURNAL 7, 306-309.

96. Ventegodt, S., Thegler, S., Andreasen, T., Struve, F., Enevoldsen, L., Bassaine, L., Torp, M., and Merrick, J. (2007). Self-reported low self-esteem. Intervention and follow-up in a clinical setting. TheScientificWorldJOURNAL 7, 299305.

97. Flensborg-Madsen, T., Ventegodt, S., and Merrick, J. (2005) Sense of coherence and physical health. A Review of previous findings. TheScientificWorldJOURNAL 5, 665-673.

98. Flensborg-Madsen, T., Ventegodt, S., and Merrick, J. (2005) Why is Antonovsky's sense of coherence not correlated to physical health? Analysing Antonovsky's 29-item sense of coherence scale (SOCS). TheScientificWorldJOURNAL 5, 767-776

99. Flensborg-Madsen, T., Ventegodt, S., and Merrick, J. (2006) Sense of coherence and health. The construction of an amendment to Antonovsky's sense of coherence scale (SOC II). TSW Holistic Health \& Medicine 1, 169-175.

100. Flensborg-Madsen, T., Ventegodt, S., and Merrick, J. (2006) Sense of coherence and physical health. A crosssectional study using a new SOC scale (SOC II). TSW Holistic Health \& Medicine 1, 236-247.

101. Flensborg-Madsen, T., Ventegodt, S., and Merrick, J. (2006) Sense of coherence and physical health. Testing Antonovsky's theory. TSW Holistic Health \& Medicine 1, 248-255.

102. Flensborg-Madsen, T., Ventegodt, S., and Merrick, J. (2006) Sense of coherence and health. The emotional sense of coherence (SOC-E) was found to be the best-known predictor of physical health. TSW Holistic Health \& Medicine 1, 183-193.

103. Hermansen TD, Ventegodt S, Rald E, Clausen B, Nielsen ML, Merrick J. (2006) Human development I: twenty fundamental problems of biology, medicine, and neuro-psychology related to biological information. TheScientificWorldJOURNAL. 6:747-59.

104. Ventegodt, S., Hermansen, T.D., Nielsen, M.L., Clausen, B., and Merrick, J.(2006) Human development II: we need an integrated theory for matter, life and consciousness to understand life and healing. TheScientificWorldJOURNAL 6, $760-766$.

105. Ventegodt, S., Hermansen, T.D., Rald, E., Flensborg-Madsen, T., Nielsen, M.L., Clausen, B., and Merrick, J. (2006).Human development III: bridging brain-mind and body-mind. introduction to "deep" (fractal, poly-ray) cosmology. TheScientificWorldJOURNAL. 6, 767-776.

106. Ventegodt, S., Hermansen, T.D., Flensborg-Madsen, T., Nielsen, M.L., Clausen, B., and Merrick, J.(2006). Human development IV: the living cell has information-directed self-organisation. TheScientificWorldJOURNAL.6, 11321138.

107. Ventegodt, S., Hermansen, T.D., Flensborg-Madsen, T., Nielsen, M.L., Clausen, B., and Merrick, J. (2006) Human development $\mathrm{V}$ : biochemistry unable to explain the emergence of biological form (morphogenesis) and therefore a new principle as source of biological information is needed. TheScientificWorldJOURNAL. 6, 1359-1367.

108. Ventegodt, S., Hermansen, T.D., Flensborg-Madsen, T., Nielsen, M., and Merrick, J. (2006). Human development VI: Supracellular morphogenesis. The origin of biological and cellular order. TheScientificWorldJOURNAL 6, 14241433.

109. Ventegodt, S., Hermansen, T.D., Flensborg-Madsen, T., Rald, E., Nielsen, M.L., and Merrick, J. (2006) Human development VII: A spiral fractal model of fine structure of physical energy could explain central aspects of biological information, biological organization and biological creativity. TheScientificWorldJOURNAL 6, 14341440 .

110. Ventegodt, S., Hermansen, T.D., Flensborg-Madsen, T., Nielsen, M.L., and Merrick, J. (2006) Human development VIII: A theory of “deep” quantum chemistry and cell consciousness: Quantum chemistry controls genes and biochemistry to give cells and higher organisms consciousness and complex behavior. TheScientificWorldJOURNAL 6, 1441-1453.

111. Ventegodt, S., Hermansen, T.D., Flensborg-Madsen, T., Rald, E., Nielsen, M.L., and Merrick J. (2006) Human development IX: A model of the wholeness of man, his consciousness and collective consciousness. 
TheScientificWorldJOURNAL 6, 1454-1459.

112. Hermansen, T.D., Ventegodt, S., and Merrick, J. (2006). Human development X: Explanation of macroevolution — top-down evolution materializes consciousness. The origin of metamorphosis. TheScientificWorldJOURNAL $\mathbf{6}$, 1656-1666.

113. Merrick, J. and Ventegodt, S. (2003) What is a good death? To use death as a mirror and find the quality in life. BMJ. Rapid Responses, 31 October.

114. Ventegodt, S. and Merrick, J., (2004) Medicine and the past. Lesson to learn about the pelvic examination and its sexually suppressive procedure. BMJ. Rapid Responses, 20 February http://bmj.com/cgi/eletters/328/7437/0g\#50997

115. Ventegodt, S, Morad, M. and Merrick, J. (2004) If it doesn't work, stop it. Do something else! BMJ Rapid Responses, 26 April. http://bmj.com/cgi/eletters/328/7446/1016-a - 57718

116. Merrick, J., Morad, M., Kandel, I. and Ventegodt, S. (2004) Spiritual health, intellectual disability and health care. BMJ Rapid Response, 16 Juli. http://bmj.bmjjournals.com/cgi/eletters/329/7458/123 - 67434

117. Ventegodt S, Morad M, Kandel I, Merrick J. (2004) Maternal smoking and quality of life more than thirty years later. BMJ Rapid Responses 30 Jul. http://bmj.bmjjournals.com/cgi/eletters/329/7460/250 - 69316

118. Merrick, J., Morad, M., Kandel, I., and Ventegodt, S. (2004) Prevalence of Helicobacter pylori infection in residential care centers for people with intellectual disability. BMJ Rapid Responses 23 July. http://bmj.bmjjournals.com/cgi/eletters/329/7459/204 - 68360

119. Merrick, J., Morad, M., Kandel, I., and Ventegodt, S. (2004) People with intellectual disability, health needs and policy. BMJ Rapid responses 20 August. http://bmj.bmjjournals.com/cgi/eletters/329/7463/414 - 71560

120. Ventegodt, S., Vardi, G. and Merrick, J. (2005) Holistic adolescent sexology: How to counsel and treat young people to alleviate and prevent sexual problems. BMJ Rapid responses $15 \quad$ Jan. http://bmj.com/cgi/eletters/330/7483/107 - 92872

121. Ventegodt, S., Flensborg-Madsen, T., and Merrick, J. (2004) Evidence based medicine in favor of biomedicine and it seems that holistic medicine has been forgotten? BMJ Rapid responses 11 Nov. http://bmj.com/cgi/eletters/329/7473/987 - 85053

122. Ventegodt, S. and Merrick, J. (2004) Placebo explained: Consciousness causal to health. BMJ Rapid responses 22 Oct. http://bmj.com/cgi/eletters/329/7472/927 - 80636

123. Ventegodt, S. and Merrick, J. (2004) Academic medicine must deliver skilled physicians. A different academic training is needed. BMJ Rapid responses 9 Oct. http://bmj.com/cgi/eletters/329/7469/0-g - 77606

124. Ventegodt, S., Morad, M., and Merrick, J. (2004) Chronic illness, the patient and the holistic medical toolbox. BMJ Rapid responses 15 Sep. http://bmj.com/cgi/eletters/329/7466/582\#74372

125. Ventegodt, S., Kandel, I. and Merrick, J. (2005). Medicine has gone astray - we must reverse the alienation now . BMJ Rapid responses 10 March. http://bmj.bmjjournals.com/cgi/eletters/330/7490/515

126. Ventegodt, S. and Merrick J. The consensus paradigm for qualitative research in holistic medicine. BMJ 2005 November 24 on-line: http://bmj.bmjjournals.com/cgi/eletters/331/7526/0-d - 122164

127. Ventegodt, S. (2006) Min brug af vaginal akupressur. (My use of acupressure.) Ugeskr Laeger 168(7), 715-716. [Danish]

128. Ventegodt, S. and Merrick, J. (2004) Philosophy of science: how to identify the potential research for the day after tomorrow? TheScientificWorldJOURNAL 4, 483-489.

129. Ventegodt, S., Merrick, J., Andersen, N.J., and Bendix, T. (2004) A combination of gestalt therapy, Rosen Body Work and Cranio Sacral therapy did not help in chronic whiplash-associated disorder (WAD) - results of a randomised clinical trial. TheScientificWorldJOURNAL 4, 1055-1068.

130. Ventegodt, S., Kandel, I., and Merrick, J. (2005) Principles of holistic medicine. Philosophy behind quality of life. Victoria, BC: Trafford

131. Ventegodt, S., Kandel, I., and Merrick, J. (2005) Principles of holistic medicine. Quality of life and health. New York: Hippocrates Sci Publ.

132. Ventegodt, S., Kandel, I., and Merrick, J. (2005) Principles of holistic medicine. Global quality of life. Theory, research and methodology. New York: Hippocrates Sci Publ

133. Technology Council (2002) Rapport from the Technology Council on alternative treatment to the Danish Parliement. 19. March 2002, Christiansborg [Danish]

\section{This article should be cited as follows:}

Ventegodt, S., Kandel, I., and Merrick, J. (2007) Quality of life and philosophy of life determines physical and mental health: status over research findings from the Quality of Life Research Center, Copenhagen, 1991-2007. TheTheScientificWorldJOURNAL: TSW Holistic Health \& Medicine 7, 1743-1751. DOI 10.1100/tsw.2007.261. 